\title{
OSCILLATION AND NONOSCILLATION CRITERIA FOR EVEN ORDER NONLINEAR FUNCTIONAL DIFFERENTIAL EQUATIONS
}

\author{
AKIHITO SHIBUYA
}

Abstract. This paper is devoted to the study of the oscillatory and nonoscillatory behavior of even order nonlinear functional differential equations with deviating argument of the type

$$
\left(p(t)\left|x^{(n)}(t)\right|^{\alpha} \operatorname{sgn} x^{(n)}(t)\right)^{(n)}+q(t)|x(g(t))|^{\beta} \operatorname{sgn} x(g(t))=0 .
$$

Mathematics subject classification (2010): 34C10, 26A12.

Keywords and phrases: even order nonlinear differential equations, oscillation, nonoscillation, regularly varying.

\section{REFERENCES}

[1] T. A. ChantURIA, Monotone and oscillatory solutions of higher-order ordinary differential equations, (Russian) Ann. Polon. Math., 37, 1 (1980), 93-111.

[2] N. H. Bingham, C. M. Goldie, J. L. Teugels, Regular Variation, Encyclopedia of Mathematics and its Applications 27, Cambridge Univ. Press, 1987.

[3] H. C. HOWARD, V. MARIĆ, Regularity and nonoscillation of solutions of second order linear differential equations, Bell. T. CXIV de Acad. Serbe Sci. et Arts, Classe Sci. mat. nat. Sci. math., 22 (1997), $85-98$.

[4] H. C. HowaRd, V. MARIĆ, Z. RADAŠIn, Asymptotics of nonoscillatory solutions of second order linear differential equations, Zbornik Rad. Prirod. Mat. Fak. Univ. Novi Sad, Ser. Mat., 20 (1990), 107-116.

[5] J. JAROŠ, T. KuSANO, Remarks on the existence of regularly varying solutions for second order linear differential equations, Publ. Inst. Math. (Beograd), 72 (2002), 113-118.

[6] J. Jaroš, T. KusAno, T. TANigAWA, Nonoscillation theory for second order half-linear differential equations in the framework of regular variation, Results Math., 43 (2003), 129-149.

[7] J. Karamata, Sur un mode de croissance régulière des fonctions, Math. (Cluj), 4 (1930), 38-53.

[8] I. T. Kiguradze, On the oscillation of solutions of the equation $d^{m} u / d t^{m}+a(t)|u|^{n} \operatorname{sign} u=0$, Mat. Sb., 65 (1964), 172-187.

[9] I. T. KiguradzE, On the question of variability of solutions of nonlinear differential equations, Differencial'nye Uravnenija, 1 (1965), 995-1006.

[10] I. T. KIgURADZE, T. A. CHANTURIA, Asymptotic properties of solutions of nonautonomous ordinary differential equations, Translated from the 1985 Russian original, Mathematics and its Applications (Soviet Series), 89, Kluwer Academic Publishers Group, Dordrecht, xiv+331 p., 1993.

[11] Y. Kitamura, T. Kusano, Nonlinear oscillation of higher-order functional-differential equations with deviating arguments. J. Math. Anal. Appl., 77, 1 (1980), 100-119.

[12] T. KuSANO, B. S. LALLI, On oscillation of half-linear functional differential equations with deviating arguments, Hiroshima Math. J., 24 (1994), 549-563.

[13] T. KusAnO, V. MARIĆ, On a class of functional differential equations having slowly varying solutions, Publ. Inst. Math. (Beograd), 80, (94) (2006), 207-217.

[14] T. KusAno, V. Marić, Slowly varying solutions of functional differential equations with retarded and advanced arguments, Georgian Math. J., 14, (2) (2007), 301-314. 
[15] T. KUSANO, V. MARIĆ, Regularly varying solutions to functional differential equations with deviating arguments, Bull. T. CXXXIV de Acad. Serbe Sci. Arts, Classe Sci. Nat., Sci. Math., 32 (2007), $105-128$.

[16] T. KusAno, M. NAITO, Unbounded nonoscillatory solutions of nonlinear ordinary differential equations of arbitrary order, Hiroshima Math. J., 18 (1988), 361-372.

[17] T. KusAno, M. NAito, Comparison theorems for functional differential equations with deviating arguments, J. Math. Soc. Japan, 33 (1981), 509-532.

[18] T. KusAno, H. ONOSE, Oscillation of solutions of nonlinear differential delay equations of arbitrary order, Hiroshima Math. J., 2 (1972), 1-13.

[19] T. KusAno, H. OnOSE, Oscillation theorems for delay equations of arbitrary order, Hiroshima Math. J., 2 (1972), 263-270.

[20] T. KusAno, J. WANG, Oscillation properties of half-linear functional differential equations of the second order, Hiroshima Math. J., 25 (1995), 371-385.

[21] W. E. Mahfoud, Comparison theorems for delay differential equations, Pacific J. Math., 83 (1979), $187-197$.

[22] J. Manojlović, T. TANigawa, Oscillation and nonoscillation theorems for a class of even-order quasilinear functional differential equations, J. Inequal. Appl., (2006) Art. ID 42120, 22 pp.

[23] V. MARIĆ, Regular Variation and Differential Equations, Lecture Notes in Mathematics, Vol. 1726, Springer-Verlag, Berlin-Heidelberg, 2000.

[24] V. MARIĆ, M. TOMIĆ, Asymptotic properties of solutions of the equation $y^{\prime \prime}=f(x) \varphi(y)$, Math. Z., 149 (1976), pp. 261-266.

[25] V. MARIĆ, M. TOMIĆ, A trichotomy of solutions of second order linear differential equations, Zbornik Rad. Prirod.-Mat. Fak. Univ. Novi Sad, Ser. Mat., 14 (1984), 1-11.

[26] V. MARIĆ, M. Tomić, A classification of solutions of second order linear differential equations by means of regularly varying functions, Publ. Inst. Math. (Beograd), 48, (62) (1990), 199-207.

[27] V. MARIć, M. TOMIć, Slowly varying solutions of second order linear differential equations, Publ. Inst. Math. (Beograd), 58, (72) (1995), 129-136.

[28] H. ONOSE, Some oscillation criteria for $n$-th order nonlinear delay-differential equations, Hiroshima Math. J., 1 (1971), 171-176.

[29] H. ONOSE, Oscillation and asymptotic behavior of solutions of retarded differential equations of arbitrary order, Hiroshima Math. J., 3 (1973), 333-360.

[30] T. TANIGAWA, Oscillation and nonoscillation theorems for a class of fourth order quasilinear functional differential equations, Hiroshima Math. J., 23 (2003), 297-316.

[31] T. TANIGAWA, Oscillation theorems for a class of even order quasilinear differential equations, Mem. Differential Equations Math. Phys., 37 (2006), 137-152.

[32] T. TANIGAWA, Oscillation theorems for differential equations involving even order nonlinear SturmLiouville operator, Georgian Math. J., 14 (2007), 737-768.

[33] T. TANigaWA, F. WU, On the existence of positive solutions for a class of even order quasilinear differential equations, Adv. Math. Sci. Appl., 14 (2004), 75-85.

[34] J. WANG, Oscillation and nonoscillation theorems for a class of second order quasilinear functional differential equations, Hiroshima Math. J., 27 (1997), 449-466. 